\title{
Kemampuan Visualisasi Siswa dalam Menyelesaikan Masalah Matematika Berdasarkan Sikap Matematis Siswa
}

\author{
Bagus Suryo Kusumo ${ }^{1 *}$, Teguh Wibowo ${ }^{2}$, Dita Yuzianah ${ }^{3}$ \\ 1,2,3 Universitas Muhammadiyah Purworejo \\ *bagussuryokusumo97@gmail.com
}

Diterima: Juni 2020. Disetujui: Juni 2020. Dipublikasikan: Juli 2020.

\begin{abstract}
ABSTRAK
Penelitian ini dilatarbelakangi karena pentingnya kemampuan visualisasi siswa dalam menyelesaikan masalah matematika. Penelitian ini dilaksanakan dengan tujuan untuk mengetahui karakteristik kemampuan visualisasi siswa dalam menyelesaikan masalah matematika berdasarkan sikap matematis siswa. Jenis penelitian ini a da lah kualitatif dengan menggunakan metode Polya untuk menganalisis timbulnya karakteristik kemampuan visualisasi. Penelitian dilakukan di SMA Purworejo pada siswa kelas X semester genap tahun ajaran 2019/2020. Subjek pada penelitian ini adalah siswa kelas X yang dipilih secara purposive sampling yaitu siswa dengan sikap matematis.Teknik pengumpulan data menggunakan angket sikap matematis, tes kemampuan visualisasi dan wawancara tidak terstruktur yang telah diva lidasi oleh ahli. Hasil penelitian tentang karakteristik kemampuan visualisasi matematis siswa dalam menyelesaikan masalah matematika yaitu, timbul ide/rencana penyelesaian akibat aktivitas memahami masalah yang dapat dilihat malalui aktivitas memahami dan penjabaran rumus yang digunakan; melaksanakan rencana (menguraikan) dan membayangkan/imajinasi visual menggunakan kemampuan analogi, terlihat pada gerakan tangan siswa yang berusaha mencocokan sesuatu dalam pemikirannya; diakhiri dengan representasi visual yang merupakan proses aktualisasi dari kemampuan visua lisa si.
\end{abstract}

Kata kunci: kemampuan, visualisasi, matematis.

\begin{abstract}
This research is motivated by the importance of student's visualization abilities in solving mathematical problems. This research was conducted with the aim to determine the characteristics of student's visualization ability in solving mathematical problems based on student's mathematical attitudes. This type of research is qualitative by using Polya method to analyze the characteristics appearance of visualization ability. The research was conducted at Purworejo Senior High School, the second semester of grade X in the year of 2019/2020. The subjects in this research were the student of grade X selected by purpo sive sampling based on student mathematical attitudes. Data collection techniques used mathematical attitude questionnaires, visualization skills test and unstructured interviews validated by the experts. The results of student's mathematical visualization abilities in solving mathematical problems are arising ideas or solving plans due to the activity of understanding problems, it can be seen through the activity of understanding and elaborating the formulas used; carry on plans (elaboration) and visual imaginations using analogy skills that can be seen in the movements of student's hands trying to match something in his thinking; ends with a visual representation which is the actualization process of the ability of visualization.
\end{abstract}

Keywords: ability, visualization, mathematical.

How to Cite: Kusumo, B. S., Wibowo, T., \& Yuzianah, D. (2020). Kemampuan Visualisa si Siswa dalam Menyelesaikan Masalah Matematika berdasarkan Sikap Matematis Siswa . Journal of Medives: Journal of Mathematics Education IKIP Veteran Semarang, 4(2), 329-338. 


\section{PENDAHULUAN}

Tujuan pembelajaran matematika menurut Kurikulum 2013 (Kemendikbud, 2013) mengedepankan dimensi pedagogik modern dalam pembelajaran, yaitu menggunakan pendekatan scientific (ilmiah). Pendekatan scientific dalam pembelajaran matematika diduga dapat menciptakan pembelajaran yang bermakna. Oleh karena itu untuk mencapai suatu pembelajaran bermakna, dalam pembelajaran dapat ditandai oleh suatu kegiatan mengamati, menanya, mencoba, menalar, menyaji, dan mencipta yang semua itu terjadi dalam suatu kegiatan proses pembelajaran siswa.

Menurut beberapa penelitian, bahwa terdapat kemudahan saat pendekatan visual atau visualisasi digunakan oleh guru untuk pembelajaran yaitu kemudahan dalam proses pembelajaran, penyelesaian masalah matematika, kemampuan matematis, dan bahkan sikap siswa. Penelitian yang berkaitan dengan visualisasi dalam pembelajaran matematika di antaranya: jenis gaya kognitif siswa berpengaruh dalam berpikir visual siswa (Ali, 2018), pendekatan Visual Thinking pada materi bilangan bulat berpengaruh signifikan terhadap kemampuan koneksi matematis siswa (Khoerunnisa, 2017), pendekatan Visual Thinking berpengaruh positif kepada sikap siswa (Nurdin, 2015), dan visualisasi mempunyai peran penting dalam menyelesaikan masalah matema-tika dan mengembangkan sikap positif siswa (Surya, 2014).
Berdasarkan uraian tentang visualisasi di atas, banyak yang meneliti visualisasi hanya sebagai pendekatannya saja. Bahwa dengan pendekatan visual akan meningkatkan kemampuan berpikir matematis siswa. Peneliti merasa perlu untuk melakukan penelitian terkait bagaimana kemampuan visualisasi siswa dalam menyelesaikan masalah matema-tika dan jika berdasarkan karakter atau veriabel tertentu yang dimiliki siswa.

Peneliti tertarik untuk mengambil sikap matematis yang dimiliki siswa sebagai variabel terikat dari subjek yang akan diteliti karena setiap orang memiliki perbedaan mengenai sikap atau ketertarikan dalam pembelajaran bahkan menyelesaikan masalah matematika (Khalid, 2007). Mengembangkan ke-mampuan matematika termasuk juga mengembangkan sikap, karena sikap adalah kecenderungan intelektual terhadap matematika atau pemecahan masalah, termasuk perspektif tentang apa itu matematika dan aktivitas matematika (Arcavi, 2007), dan sikap matematis merupakan pendorong yang penting dari ketegori/jenis berpikir yang lain dalam berpikir matematika (Katagiri, 2004).

Dari penjabaran sikap matematis di atas, adapun siswa dengan sikap matematis menurut Katagiri (2004) memiliki tipe (jenis/corak) yang tergolong sikap matematis siswa dalam menyelesaikan sebuah permasalahan matematika adalah sebagai berikut. (1) Berusaha untuk memahami masalah atau tujuan atau substansi seseorang dengan jelas, sendirian; (2) berusaha 
mengambil tindakan logis; (3) berusaha mengung-kapkan hal-hal dengan jelas dan ringkas; (4) berusaha mencari halhal yang lebih baik.

Berdasarkan uraian di atas, peneliti merasa perlu untuk melakukan penelitian terkait dengan kemampuan visualisasi siswa dalam menyelesaikan masalah matematika berdasarkan sikap matematis siswa. Sebab sikap matematis merupakan kekuatan pendorong yang paling dasar dalam berpikir matematis (Katagiri, 2004). Disinilah yang melan-dasi pertanyaan peneliti, "Bagaimana kemampuan visualisasi siswa jika diteliti berdasarkan sikap matematis yang dimiliki siswa?" Dengan begitu hasil penelitian ini diharapkan dapat dijadikan sebagai bahan informasi ataupun evaluasi bagi para guru dalam meningkatkan kemampuan visualisasi siswa pada proses pembelajaran terutama membantu siswa untuk mengonstruksi kemampuan berpikir matematisnya dalam menyelesaikan masalah matematika. Adapun tujuan penelitian ini untuk mengetahui dan mendiskripsikan karakteristik kemampuan visualisasi dalam menyelesaikan masalah matematika berdasarkan sikap matematis siswa.

\section{METODE PENELITIAN}

Jenis penelitian yang dipilih yaitu penelitian kualitatif. Penelitian kualitatif adalah penelitian yang bermaksud untuk memahami fenomena tentang apa yang dialami oleh subjek penelitian secara keseluruhan, dan dengan cara penjelasan dalam bentuk kata-kata dan bahasa, pada suatu konteks khusus yang alamiah dan dengan memanfaatkan berbagai metode alamiah (Moleong, 2014). Penelitian kualitatif dapat diibaratkan sebagai se-helai kain yang rumit (Creswell, 2014). Untuk mengetahui dan memahami arah, maksud atau fenomena dari sehelai kain yang rumit (data dalam suatu penelitian kualitatif) ini dengan cara menganalisis dan mendiskripsikannya melalui berbagai asumsi umum dan kerangka penafsiran yang saling jalin-menjalin serta mendukung fokus suatu penelitian.

Jadi dapat diketahui bahwa penelitian kualitatif adalah suatu cara penelitian yang bermaksud untuk memahami atau menjelaskan fenomena yang dialami oleh subjek penelitian, dimana peneliti adalah sebagai instrumen kunci dan hasil penelitian kualitatif lebih menekankan makna dari pada generalisasi.

Pendekatan yang digunakan dalam penelitian ini adalah pendekatan grounded theory. Grounded theory adalah pendekatan metode penelitian kualitatif yang menggunakan seperangkat prosedur sistematik untuk mengembangkan teori dari bawah yang diperoleh secara induktif tentang suatu fenomena (Moleong, 2014). Grounded theory juga bisa dipahami sebagai desain yang baik untuk digunakan ketika tidak didapatkan teori untuk menjelaskan atau memahami proses (Creswell, 2014). Jadi dapat diketahui bahwa tujuan grounded theory adalah suatu pendekatan dalam penelitian kualitatif untuk menjelaskan atau memahami proses, kejadian atau fenomena karena teori yang dihadirkan kurang lengkap dan belum secara jelas 
menerangkan fenomena tersebut. Penelitian ini nantinya akan didapatkan data deskriptif berupa uraian yang menjelaskan kemampuan visualisasi dalam menyelesaikan masalah matematika berdasarkan sikap matematis siswa.

Penelitian ini dilaksanakan di salah satu sekolah jenjang SMA di Kabupaten Purworejo. Waktu pelaksanaan dimulai pada bulan Oktober 2019 hingga Agustus 2020 di kelas X SMA di Purworejo tahun ajaran 2019/2020 pada materi sistem pertidaksamaan dua variabel.

Subjek penelitian adalah siswa yang memiliki sikap matematis yang memenuhi minimal satu tipe (jenis) dari empat tipe sikap matematis menurut Katagiri (2004) dengan angket yang sudah divalidasi oleh ahli, wawancara dan pertimbangan teknik purposive peneliti. Kemudian akan diamati kemampuan visualisasi yang dimiliki subjek melalui tes khusus untuk melihat proses karakteristik kemampuan visualisasi melalui tahapan analisa penyelesaian masalah menurut Polya. Diakhiri dengan wawancara khusus untuk memantapkan hasil tes yang didapat dalam mengetahui dan memahami secara mendalam kemampuan visualisasi yang dimiliki subjek penelitian serta mencapai kejenuhan data. Adapun teknik pengum-pulan data yang digunakan adalah angket, tes, wawancara, dokumentasi, dan catatan lapangan.

Dalam penelitian ini, peneliti menggunakan instrumen pendukung pada pengumpulan data yaitu angket sikap matematis model terbuka yang dikembangkan sesuai dengan sikap matematis menurut Katagiri (2004), soal tes visualisasi, dan wawancara tidak ter-struktur yang telah divalidasi oleh dua dosen dari pendidikan matematika dengan maksud untuk menguatkan kevalidan instrumen. Gambar 1 menjelaskan instrumen

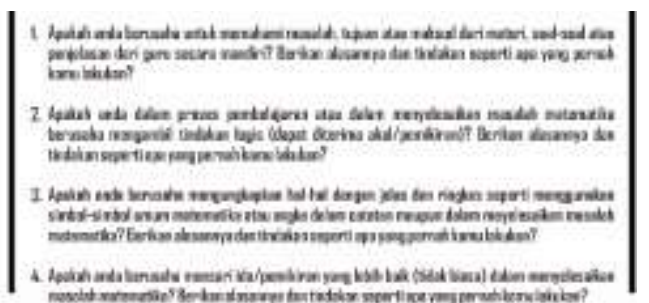

Gambar 1. Lembar Angket

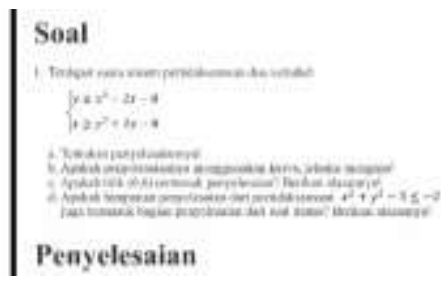

Gambar2. LembarTes Visualisasi

pendukung untuk pengumpulan data berbentuk lembar angket.

Menurut Widoyoko (2012: 33), angket atau kuesioner merupakan metode pengumpulan data yang dilakukan dengan cara memberi seperangkat pertanyaan atau pernyataan tertulis kepada responden untuk diberikan respon sesuai dengan permintaan pengguna". Peneliti menggunakan instrumen angket model terbuka seperti Gambar 1. Tujuan peneli-ti adalah dapat memaknai apa yang di-ungkapkan siswa terkait sikap matema-tis atau pribadi diri siswa terhadap mate-matika secara mendalam dan mengkon-firmasinya saat sesi wawancara angket.

Menurut Djemari (Widoyoko, 2012), "tes merupakan salah satu cara untuk menaksir besarnya kemampuan seseorang secara tidak langsung, yaitu 
melalui respons seseorang terhadap stimulus atau pertanyaan". Berdasarkan Gambar 2, peneliti menggunakan instrumen soal tes kemampuan visualisasi. Materi yang digunakan adalah sistem pertidaksamaan dua variabel. Disini peneliti menggunakan tahapan penyelesaian masalah menurut Polya untuk menganalisis pemetaan timbulnya kemampuan visualisasi siswa. Kemudian pada soal nomer $1 \mathrm{c}$ dan $1 \mathrm{~d}$, disini peneliti bertujuan untuk memperlihatkan tahapan memeriksa kembali yang telah dilakukan siswa.

Teknik analisis data yang digunakan adalah teknik analisis data Miles \& Huberman (Sugiyono, 2009) sebagai berikut. (1) Reduksi data (data reduction); (2) penyajian data (data display); dan (3) penarikan kesimpulan (conclusion drawing/verification). Teknik keabsahan datanya menggunakan triangulasi teknik.

\section{HASIL DAN PEMBAHASAN}

Peneliti memilih dan menganalisis jawaban angket siswa dengan keaktifan serta sikap positif siswa terhadap matematika saat pembelajaran di kelas dan keberanian menjawab "YA" terbanyak (mendekati sempurna) sekaligus mampu menjelaskan dari ke-4 pertanyaan yang telah diajukan untuk masuk ke tahap wawancara sikap matematis yang bersifat konfirmasi dan memeriksa kembali jawaban dari angket siswa. Gambar 3 menunjukan lembar jawaban sikap matematis yang dimiliki MS yaitu siswa kelas X SMA di

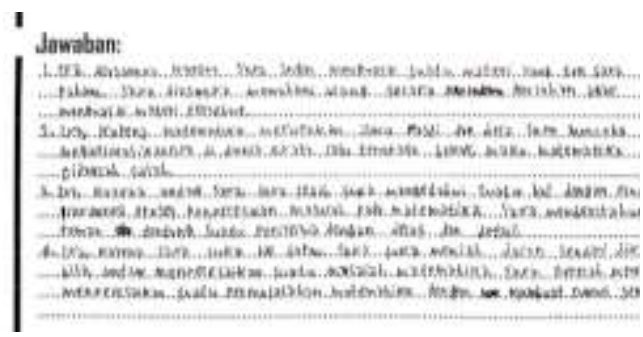

Gambar 3. Lembar Jawaban Angket Sikap
Purworejo.

Tabel 1. Hasil Pengerjaan

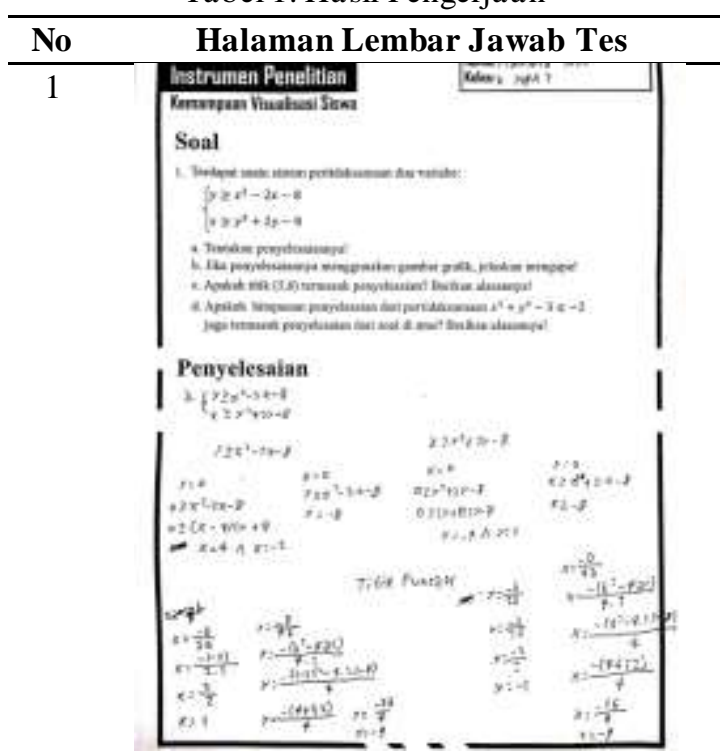

2

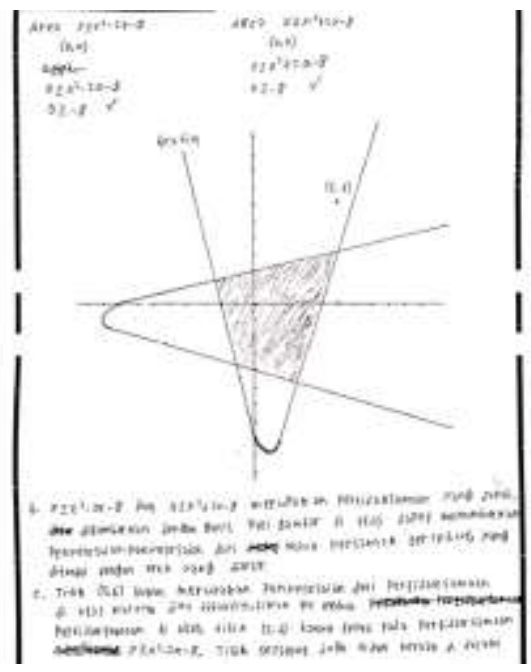




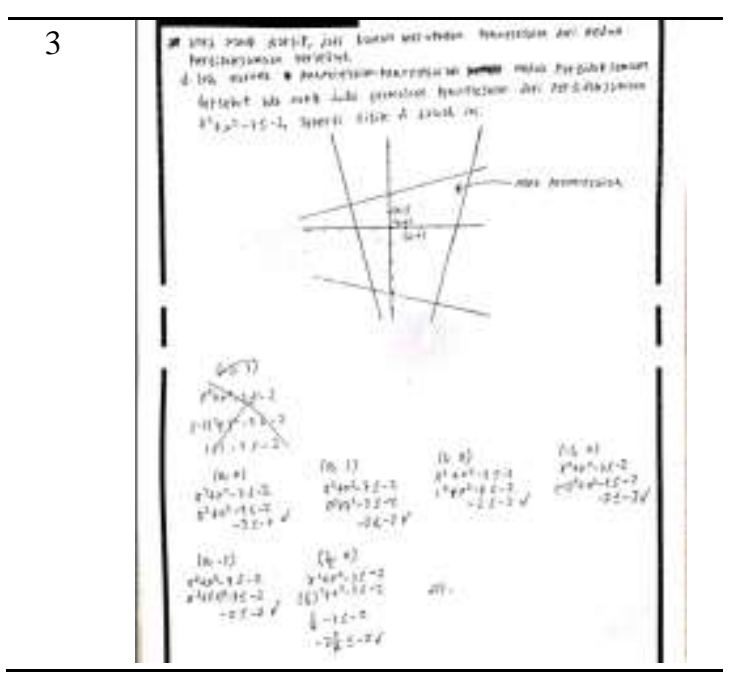

Pada lembar jawaban angket tersebut, MS menunjukan keberanian untuk menjawab "Ya" pada keempat pertanyaan yang telah diajukan. Setelah dilakukannya wawancara MS menunjuk-kan respon yang positif dan berusaha menjelaskan serta mempertahankan kebenaran atas jawabannya. Sehingga peneliti yakin memilih MS untuk dijadikan subjek yang akan dilihat bagaimana kemampuan visualisasi yang dimiliki.

Analisis kemampuan visualisasi siswa diamati berdasarkan proses siswa dalam menyelesaikan masalah sistem pertidaksamaan dua variabel. Tabel 1 merupakan jawaban tes kemampuan visualisasi MS. Berikut paparan dan analisis kemunculan kemampuan visualisasi MS dalam menyelesaikan masalah matematika. Pertama, MS mulai mengerjakan soal/masalah matematika dengan membaca pertanyaan selama 30 detik. Gerakan bola mata MS yang dengan seksama menganalisa masalah, itu menandakan MS mencoba mengenali atau mengidentifikasi masalah yang telah diberikan.

Kemudian, MS mulai menuliskan rumus untuk mengolah informasi dalam soal serta sesekali MS juga menggerakgerakan tangannya seperti membayangkan sesuatu pola dan mencocokan dengan hasil yang didapat. Seperti yang ditunjukan pada Gambar 4, rencana penyelesaian tersebut menandakan MS mencoba mengolah informasi soal dengan menentukan rencana/cara penye-lesaian sesuai pengalaman

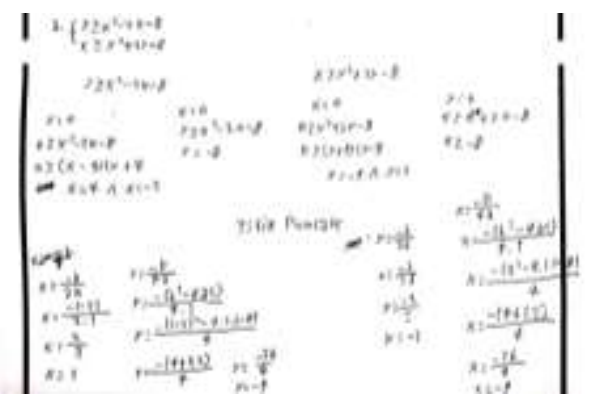

Gambar4. Rencana Penyelesaian

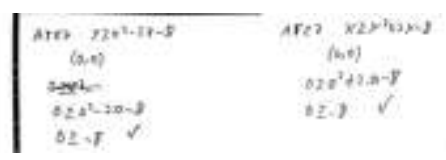

Gambar 5. Menentukan Area Penyelesaian

pengetahuan-nya berupa rumus titik potong dengan garis sumbu dan mencari titik puncaknya serta mencoba mencari hubungan antara hasil yang diperoleh dari rumus yang digunakan dengan apa yang terbayang-kan dalam pemikiran MS (imajinasi).

Setelah itu, MS langsung menentu-kan area penyelesaiannya dengan mensubtitusikan titik $(0,0)$ kedalam kedua pertidaksamaan dalam soal tersebut. Terlihat MS sudah memba-yangkan dan menemukan sesuatu pola tertentu untuk penyelesaian 
soal terse-but. Kemudian, menggunakan langkah ini untuk mencari area penyelesaian sesuai pengetahuan yang telah dimilikinya (seperti yang ditunjukan pada Gambar 5).

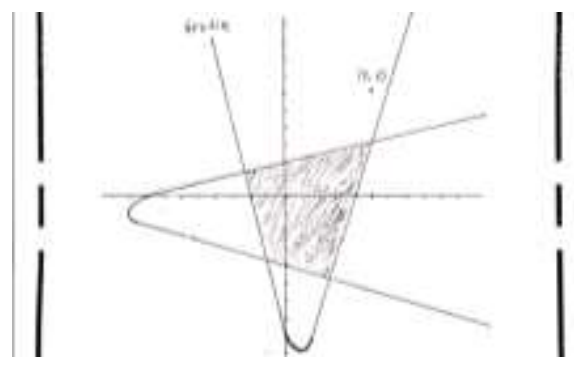

Gambar6. Hasil Proses Analogi

Selanjutnya, MS mulai menggambar kurva yang terbentuk dengan sesekali melihat kembali hasil yang diuraikan sebelumnya. Hal ini menanda-kan MS mencoba menyimpulkan keseluruhan hasil informasi yang telah diolah dan bentuk visual yang telah dibayangkan, serta berusaha membentuk representasi yang sempurna. Disini MS menggunakan penggaris dalam proses menggambar. Meski terlihat cukup rapi, tetapi hal ini tidak benar. Asumsi peneliti menduga, bahwa MS berusaha untuk memberikan kejelasan dan kesempur-naan penyelesaian yang didapatkan (Gambar 6).

Pada soal nomor 1c dan 1d, MS menjawabnya dengan cukup baik dan memberikan penjabaran. Hal ini terlihat dengan jelas MS melakukan tahap memeriksa kembali sesuai tahapan penyelesaian menurut Polya. Tetapi, jawaban MS pada nomer 1c yang tertuliskan “.... titik $(5,6)$ hanya tepat pada pertidaksamaan $y \geq x^{2}-2 x-8$ ...., ini tidak dibenarkan. Dugaan peneliti, MS terpengaruh gambarnya yang kurang proposional karena hal ini terlihat pada kebenaran penjelasan berikutnya.

MS juga dapat menjelaskan pertanyaan soal nomer $1 \mathrm{~b}$, tentang mengapa penyelesaiannya tersebut menggunakan

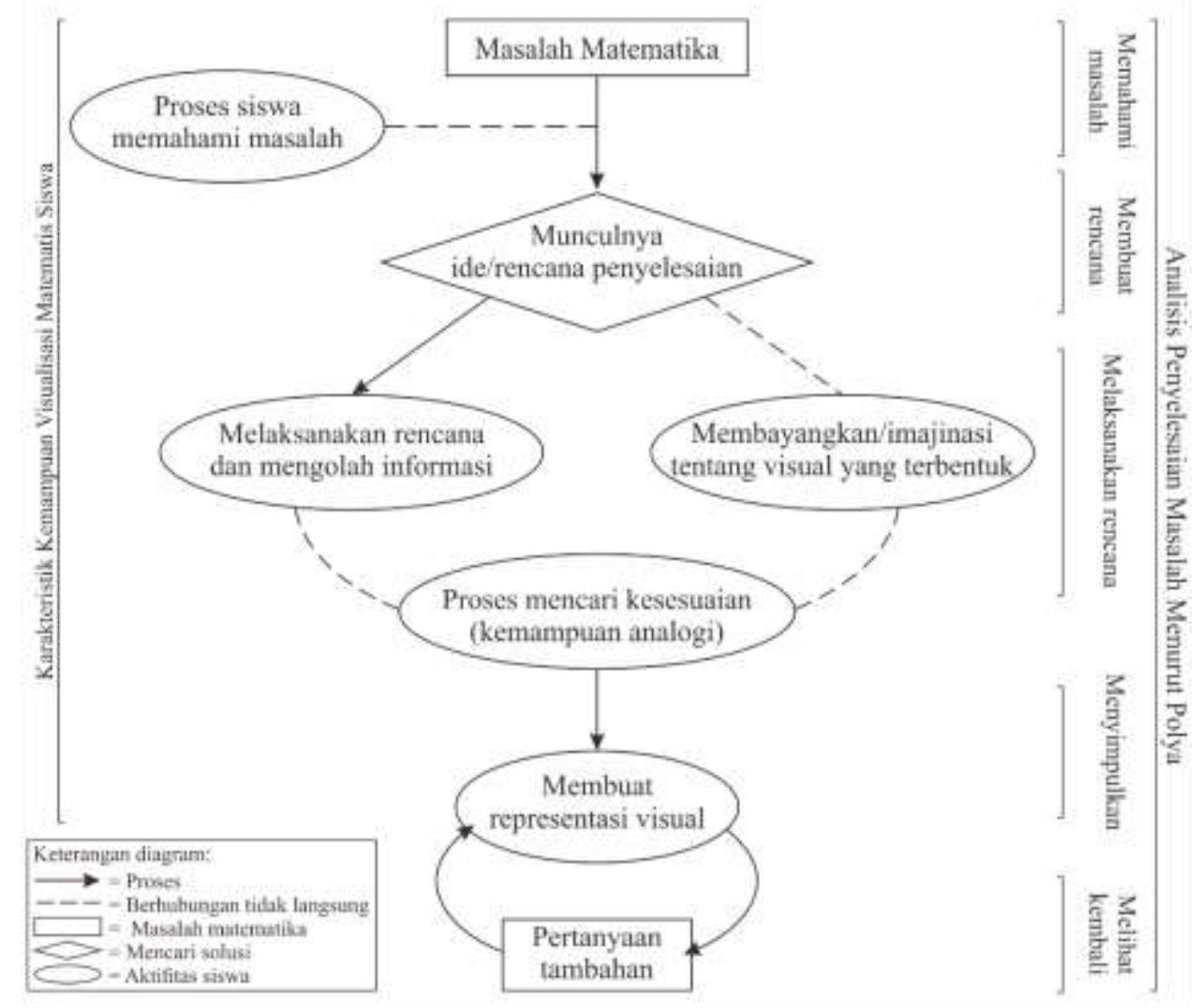

Gambar7. Diagram Proses Munculnya Kemampuan Visualisasi Matematis Siswa Berdasarkan Sikap 
visual atau gambar kurva. Terlihat pada lembar jawab MS dan juga saat wawancara MS menjelaskan alasannya yaitu, "supaya lebih mudah dipahami karena semua titik-titik yang berada di area terarsir itu merupakan penyelesaian dan menggunakan gambar akan mudah untuk memahaminya". Hal ini menanda-kan MS telah mengerti mengapa penyelesaian sistem pertidaksamaan selalu menggunakan kurva (visual).

Penjabaran di atas merupakan hasil yang telah ditemui peneliti saat di lapangan dan diperoleh diagram proses munculnya kemampuan visualisasi matematis siswa seperti Gambar 7 . Kemudian, peneliti mencoba untuk melakukan pembahasan lebih mendalam tentang kemampuan visualisasi matema-tis siswa. Kemampuan visualisasi matematis siswa pada penelitian ini diwakili oleh MS siswa kelas X SMA di Purworejo tahun ajaran 2019/2020 dengan sikap matematis yang dimiliki mendekati sempurna sesuai indikator yang diungkapkan oleh Katagiri. Hal ini bertujuan untuk memeperoleh infomasi yang maksimal mengenai karakteristik kemampuan visualisasi siswa dalam menyelesaikan masalah matematika.

Kemunculan kemampuan visualisasi didapat dari proses penyelesaian sistem pertidaksamaan dua variabel. Dimulai dangan gerakan bola mata yang seksama membaca pertanyaan dan memahami secara keseluruhan. Tahap ini sesuai dengan pendapat Polya (1973) tentang tahap awal penyelesaian masalah matematika yaitu memahami masalah.
Setelah kegiatan memahami jenis, maksud dan tujuan soal, MS menentukan rencana/cara penyelesaian sesuai penga-laman pengetahuannya. Ini sesuai dengan pendapat Polya (1973) tentang tahap membuat rencana penyelesaian setelah memahami masalah. Ini merupa-kan ide dalam penyelesaian dan dilanjut-kan dengan MS mengolah informasi pada soal serta melaksanakan rencana penyelesaian. Tahap ini juga sesuai dengan pendapat Polya (1973) tentang tahap melaksanakan rencana penye-lesaian setelah membuat rencana penyelesaian.

Selama proses melaksanakan rencana (mengolah informasi), MS mencoba membayangkan secara imajinasi visual untuk mencari hubungan antara hasil yang diperoleh dari rumus dan imajinasi visual yang dibayangkan dalam pemikirannya. Hal ini merupakan kegiatan proses analogi sesuai pendapat Wibowo (2017), tentang karakteristik imajinasi matematika sensori, salah satunya munculnya analogi untuk mengolah informasi yang ada. Ini juga menguatkan pendapat Surya (2010) tentang definisi visual thinking khususnya dalam kemampuan proses analitis dan interaksi antara memahami (melihat), menafsirkan (membayangkan), dan memproduksi (menggambarkan). Tahap analogi atau proses analitis ini dilakukan oleh MS secara berulang selama proses pengerjaan berlangsung.

Kemudian MS mencoba melakukan represesntasi visual sempurna sesuai langkah penyelesaian yang telah diketa-huinya dan mengolah seluruh pemaparan serta imajinasi untuk tujuan menunjukan penyelesaian masalah 
(tahap aktualisasi dari proses kemampuan visualisasi siswa). Terlihat dari usaha MS menyem-purnakan hasil visualnya mengunakan penggaris (walaupun tidak dibenarkan) dan cukup baik menunjukan tahapan penyelesaian masalah yaitu memeriksa kembali sesuai dengan pendapat Polya.

Dalam hal ini seluruh proses penyelesaian masalah matematika dari munculnya ide/rencana penyelesaian akibat memahami masalah, kemudian proses mengolah informasi dan membayangkan menggunakan analogi serta diakhiri dengan representasi visual merupakan karakteristik kemampuan visualisasi matematis siswa. Siswa juga menunjukan sikap matematis yang cukup baik dalam menjelasakan dan memaparkan pertanyaan lainnya. Ini memperkuat pendapat Katagiri (2004) bahwa sikap matematis merupakan jenis pemikiran matematis yang mendorong untuk berpikir matematis lainnya, salah satunya berpikir analogi.

\section{PENUTUP}

Proses siswa dalam penyelesaian masalah matematika ini dimulai dari siswa memahami masalah yang diberikan sehingga muncul ide/rencana yang sesuai untuk penyelesaian, kemudian proses melaksanakan rencana (mengolah informasi) terdapat kegiatan memba-yangkan (merepresentasikan informasi menggunakan analogi) sesuai dengan rumus yang dipahami dan proses imajinasi visual siswa. Setelah itu, siswa merepresentasikannya berupa visual yang merupakan hasil penyelesaian masalah matematika.
Karakteristik kemampuan visualisasi matematis siswa yang muncul dalam menyelesaikan masalah matematika yaitu, timbul ide/rencana penyelesaian akibat aktivitas memahami masalah yang dapat dilihat pada proses penjabar-an rumus yang digunakan; melaksana-kan rencana (proses memperoleh infomasi lanjutan untuk diolah) dan membayangkan/imajinasi visual meng-gunakan kemampuan analogi terlihat pada gerakan tangan siswa yang menco-cokkan sesuatu dalam pemikirannya; serta diakhiri dengan representasi visual yang merupakan hasil aktualisasi dari kemampuan visualisasi matematis siswa.

\section{DAFTAR PUSTAKA}

Ali, W. (2018). Deskripsi Tingkat Berpikir Visual dalam Memahami Definisi Formal Barisan Bilangan Real Berdasarkan Gaya Kognitif Mahasiswa Jurusan Matematika UNM. Makassar: eprints. Tersedia: http://eprints.unm.ac.id/10726/1/a rtikel\%20penelitian.pdf diakses pada tanggal 9 November 2019 pukul 20.47 WIB

Arcavi, A. (2007). Mathematical thinking in japanese classrooms. Tersedia: https://apec.org//media/APEC/Publications/2008/3 /Collaborative-Studies-onInnovations-for-Teaching-andLearning-Mathematics-inDifferent-CulturesII/TOC/Keynote-Speech-5Mathematical-Thinking-inJapanese-Classrooms.pdf diakses pada tanggal 9 November 2019 pukul 20.49 WIB 
Creswell, John W. (2014). Penelitian Kualitatif \& Desain Riset. Yogyakarta: Pustaka Pelajar.

Katagiri S. 2004. Mathematical thinking and how to teach it. E-book (online). Tersedia: http://earchives.criced.tsukuba.ac.jp/data/ doc/pdf/2009/02/Shigeo_Katagiri. pdf diakses pada tanggal 6 November 2019 pukul 07.15 WIB

Kemendikbud. (2013). Kerangka Dasar dan Struktur Kurikulum 2013. Jakarta: Kemendikbud.

Khalid, M. (2007). Incorporating mathematical thinking in addition and substraction of fraction: real issues and challenges. Tersedia: www.crme.kku.ac.th/APEC/PDF \%202007/Madihah\%20Khalid.pdf diakses pada tanggal 6 November 2019 pukul 07.15 WIB

Khoerunnisa, D. (2017). Pengaruh Pendekatan Visual Thinking terhadap Kemampuan Koneksi Matematis Siswa. Jakarta: FITK UIN Syarif Hidayatullah Jakarta

Nurdin, E. (2015). Pengaruh Pembelajaran dengan Pendekatan Visual Thinking Terhadap Sikap Siswa. Journal AdMathEdu Vol.5 No. 2

Polya, G. (1973). How To Solve It. New Jersey : Princeton University Press. Tersedia: https://notendur. hi.is/hei2/teaching/Polya_HowTo SolveIt.pdf diakses pada 7 November 2019 pukul 20.14 WIB

Sugiyono. (2016). Memahami Penelitian Kualitatif. Bandung: Alfabeta

Surya, E. (2010). Visual Thinking dalam Memaksimalkan Pembelajaran Matematika Siswa dapat Membangun Karakter Bangsa. Journal Abmas Tahun 10
Nomor $10 \quad$ Oktober 2010.

Tersedia:

http://jurnal.upi.edu/abmas/view/4

00/visual-thinking-dalam-

memaksimalkan--pembelajaran-

matematika-siswa--dapat--

membangun-karakter-bangsa.html

diakses pada tanggal 5 November 2019 pukul 08.40 WIB

Surya, Edy (2012) Visual Thinking dalam Memaksimalkan Pembelajaran Matematika Siswa dapat Membangun Karakter Bangsa. Jurnal Penelitian dan Pembelajaran Matematika Vol.5 No.1. pp. 41-50. ISSN 1979-3545. Tersedia: http://digilib.unimed.ac.id/817/.

Diakses pada tanggal 6 November 2019 pukul 07.49 WIB

Surya, E. (2014). Memicu Visualisasi dan Kreativitas dalam Pembelajaran Matematika Membentuk Karakter Positif Siswa. Jurnal Tematik Vol 4, No 02 . Tersedia: https://jurnal.unimed.ac.id/2012/in dex.php/tematik/article/view/3159 siakses pada tanggal 6 November 2019 pukul 07.15 WIB

Moleong, L. J. (2014). Metodologi Penelitian Kualitatif. Bandung: PT. Remaja Rosdakarya

Wibowo T, dkk. 2017. Characteristics of Students Sensory Mathematical Imagination in Solving Mathematics Problem. Indonesia: International Electronic Journal of Mathematics Education Open Access, Volume 12 Issue 3, pp. 609-619

Widoyoko, E. P. 2012. Teknik Penyusunan Instrumen Penelitian. Yogyakarta: Pustaka Pelajar. 